\title{
The Reflection of Carlos Castaneda and His Work in the Milieu of Contemporary Czech Shamanism
}

\author{
Helena Dyndová
}

https://doi.org/10.14712/25704893.2020.1

\begin{abstract}
The article deals with the analysis of Carlos Castaneda's legacy in the contemporary Czech shamanic milieu, with his literary successors, and with continuity of his teachings explained in famous decalogy about shaman-sorcerer don Juan. The first part is dedicated to the zeitgeist of Castaneda's writings, focusing on Mircea Eliade's and Michael Harner's influence. The second part analyses more narrowly the reflection on Castaneda's personality and work from the current shamanic point of view. The following part introduces Castaneda's literary impact within the specific Czech context and discusses his more successful followers. The last part compares the message of Castaneda's work and current Czech shamans' teachings considering the similarities and differences, namely the relationship with nature and with spiritual allies, following with shaman's image, purpose, and responsibility. The article concludes that despite respecting Castaneda's importance in the history of shamanic revival, the contemporary Czech shamans share little with the original Castaneda's teachings.
\end{abstract}

Keywords: Contemporary shamanism; Czech shamanism; Neo-Shamanism; Contemporary Spirituality; Czech Spirituality; Carlos Castaneda

\begin{abstract}
Abstrakt: Článek se zabývá analýzou odkazu Carlose Castanedy v současném českém šamanském prostředí, zmiňuje jeho knižní následovníky a analyzuje kontinuitu Castanedova učení, které je vylíčeno v slavné knižní dekalogii o šamanovi-kouzelníkovi donu Juanovi. První část se věnuje duchu doby, ve které Castaneda své dílo tvořil, s důrazem na vliv Mircea Eliada a Michaela Harnera. Druhá část se již plně soustředí na analýzu Castanedovy osobnosti a díla očima současných šamanů. Následující část uvádí Castanedův literární odkaz do českého kontextu a představuje jeho úspěšné literární pokračovatele. Poslední část srovnává poselství Castanedova díla s učením současných českých šamanů s ohledem na podobnosti a rozdílnosti. Jmenovitě se zabývá vztahem šamana k přírodě a duchovním spojencům, dále pak obrazem šamana, jeho údělem a zodpovědností. Dochází se k závěru, že ačkoli současní šamané respektují Castanedovu důležitost pro oživení šamanismu, sami s jeho učením nijak zvlášt nesouzní.
\end{abstract}

Klíčová slova: současný šamanismus; český šamanismus; neošamanismus; současná spiritualita; česká spiritualita; Carlos Castaneda

Received: 6 September 2019, Accepted: 2 October 2019

Published online: 2 October 2020

Helena Dyndová, Department of Philosophy and Religious Studies, Faculty of Arts, Charles University

E-mail: helena.dyndova@gmail.com

(C) 2020 The Author. This is an open-access article distributed under the terms of the Creative

Commons Attribution License (http://creativecommons.org/licenses/by/4.0). 
Whether or not Don Juan lived, I don't care. Even if it was just a functional story, I'm fine with that. Because, in the same way, I can think of myself: Does Tolkien invented Arda or does it exist somewhere ?' Is this another version of our world? I'm trying to solve how shamanism and other mind-changing teachings enter other realities. This world has its reality that we now perceive. But it also has other realities, that we perceive while entering an altered state of consciousness. [...] Here you are ... [you], but if you go to another layer [of reality], you have a completely different story there, and you're someone else. ${ }^{2}$

As the title indicates, the central theme of this article will be the reflection of the prominent shamanovelist ${ }^{3}$ Carlos Castaneda and his work in the context of contemporary Czech shamanism. ${ }^{4}$ Its claims and the following analysis are based on my field research, conducted between 2017 and 2019. The research design was open and used the method of participant observation applied to contemporary shamanic practice, combined with semi-structured and informal interviews with professional shamans, long-term trainees, and enthusiasts. ${ }^{5}$

The current Czech shamanic milieu grew into its local specificities - for example that the translations of essential New Age (and shamanic) books were only available after 1989 - after the fall of the Iron Curtain. ${ }^{6}$ This access to formerly inaccessible literature dramatically changed the mood and preferences of "spiritual seekers". Because of this delay, Carlos Castaneda was not the first to come up with the discovery of the shamans' path, but rather one of many. That might explain his slightly lower popularity compared to the popularity of his literary successors.

These facts notwithstanding, Castaneda's legacy plays a vital role in contemporary Czech shamanism, and Czech shamans are familiar with his work. This article attempts to discuss firstly how Castaneda's works match with other important shamanic publication (regarding the accessible translations to Czech); secondly the reflection of Carlos Castaneda's character and the nature and authenticity of his writings;

1 Arda is a land in Tolkien's Lord of the Rings universe.

2 Interview with shaman V., July 12th, 2018. All the respondents I quote in this article knew about my research and my academic interest. However, in order to protect their identities, their names are anonymized under their initials.

3 The shamanologist Daniel Noel coined the pun "shamanovelist" as a label for authors who formed and shaped the image of shamans. DANiel C. Noel, chap. "Lying with Shamanovelists", in The Soul of the Shamanism: Western Fantasies, Imaginal Realities, New York: Continuum 1997, p. 63-82.

4 I decided to respect the slightly pejorative connotation in the shamanic environment and chose to refer to my respondents as to current/contemporary shamans instead of 'neoshamans'. For a more precise discussion of this emic/ethic issue, see Robert J. WALLIS, Shamans/Neo-Shamans: Ecstasy, Alternative Archaeologies and Contemporary Pagans, London and New York: Routledge, 2003, p. 27-34. At the same time, I intentionally skip the discussion about the definition of the terms 'shaman' and 'shamanism'. For a thorough analysis of academic discussion see LARS KIRKHUSmo Pharo, “A Methodology for a Deconstruction and Reconstruction of the Concepts 'Shaman' and 'Shamanism'”, Numen: International Review for the History of Religions 58 (1, 2011): p. 6-70.

5 The methodological approaches are more precisely described in HelenA ExNERová, Český šamanismus v rozhovorech [Czech Shamanism in Dialogues], Praha: Dingir 2018, 228 p.

6 Cf. Zdeněk Nešpor and Olga Nešporová, "Religion: An Unsolved Problem for the Modern Czech Nation”, Czech Sociological Review 45 (6, 2009): p. 1215-1237. 
and thirdly the similarities and differences between Castaneda's worldview comparing to current Czech shamanic teachings. Still, at this point of departure, it shall be noted that Czech shamans are a very diverse group. This article attempts to search for shared points of emphasis and to compare a comprehensive complex of thoughts on the one hand and its remnants in a very individualistic spiritual practice on the other hand. With a dose of generalization, let us proceed to a summary of the parts of Castaneda's legacy which remained in the perception of the practice.

\section{Shamanism and Print Culture}

Shamanism, as practiced today, was invented primarily based on the literature that described it, whether these be academic or experimental works (or a combination of both styles). Since the beginning of the 20th century, the image of shamanism has been predominantly determined by anthropologists who studied "shamanic" cultures and who later recognized shamanism in various cultures worldwide. Over in three hundred years of study, the general impression about shamanism has changed from demonization or medicalization to a more sensitive and understanding approach, which culminated in the 1960 s as a mainstream admiration of shamans and their work. ${ }^{7}$

No wonder that many anthropologists writing about shamanism (shamanovelists) eventually became shamans (shamanthropologists) ${ }^{8}$ themselves. ${ }^{9}$ Conversely, many contemporary shamans from traditional societies started to read books written by these shamanovelists and then use them to teach people who come to seek "authentic indigenous spirituality" or reconstruct their pre-Christian religion. ${ }^{10}$ Moreover, many Western seekers have become contemporary shamans by reading these books.

Thus, a kind of a book universe has been created, in which "traditional" shamans and shamanism gradually acquired a solid identity in popular discourse: A shaman is understood to be a noble savage, or more precisely a "noble Indian"; an extraordinary human being able to communicate with the world or worlds beyond ourselves. Shaman is a healer, a medicine man or woman, a wise figure, an extraordinary creative personality associated with the unspoiled ancient world of archaic wisdom that "we" have already lost. Through shamanism and its techniques, modern western spiritual-

\footnotetext{
7 The history of the term "shaman" is long and complicated, full of researchers' projections, biases, and shifts in definitions. For a thorough summary see, ANDrei A. ZnAmenski, The Beauty of the Primitive: Shamanism and the Western Imagination, Oxford: Oxford University Press 2007, 434 p., or, Jeroen W. Boekhoven, Genealogies of Shamanism: Struggles for Power, Charisma and Authority, Groningen: Barkhuis 2011, 383 p.

${ }^{8}$ A similar pun used by Noel, The Soul of the Shamanism ..., p. 83-105 (chap. "Studying with Shamanthropologists").

9 A Czech example of a shamanthropologist would be Pavlína Brzáková.

${ }^{10}$ Znamenski, The Beauty of the Primitive, p. 364. For a harsher anthropological critic see Alice Beck Keнoe, Shamans and Religion: An Anthropological Exploration in Critical Thinking, Long Grove: Waveland Press 2000, 125 p.
} 
ity has tried to set off on a path leading to authentic spirituality, to one's true self, to a union with the universe or nature's forces, to happiness and health, and other spiritual goals typical for the New Age milieu. ${ }^{11}$

The scholar of religion, Mircea Eliade, played a crucial role in the shift of how the term 'Shaman' is interpreted, which is still present in the Czech spiritual milieu. His ground-breaking book Shamanism: Archaic Techniques of Ecstasy (1964) ${ }^{12}$ has become a bestseller and the most cited book on shamanism for many years, and for a long time, the only book translated into Czech accepted by a wider non-academic audience. ${ }^{13}$ His book accommodated the discourse about shamans in the contemporary Czech shamanism as well: current shamans perceive the shaman as a master of ecstasy, who is not controlled by otherworldly powers, but who mastered them and can use them. The shaman makes direct, non-mediated contact with Eliade's "sacred". ${ }^{14}$

After the first wave of awe, many scholars revised Eliade's theories on shamanism and describe them more sceptically as Eliade's myth about shamanism or even Eliade's wishful thinking. ${ }^{15}$ Eliade's suggestive literary work (in which Eliade is similar to Castaneda) showed indigenous spirituality as worthy of Western spiritual interest and allowed shamanism to be perceived as a universal and primary ("archaic") religious technique. ${ }^{16}$ Eliade's successors, in their initial uncritical enthusiasm, also recognized shamanism in the history of their field.

The University of California in Los Angeles, the 'alternative spirituality Mecca of the $1960 \mathrm{~s}^{17}$ was generally full of people "anxious to explore such topics as spirituality, shamanism, and altered states"; the latter being inspired by Eliade. ${ }^{18}$ The anthropology department, where Castaneda studied, was no exception. This stimulating environment largely influenced Castaneda who wanted to earn his spurs.

His first three monographs about the sorcerer Don Juan became a bestseller for a time and, despite their fraudulent nature, they have been crucial for modern shamans. Why? While Eliade wanted to find spiritual redemption from the fallen Western secularism in his form of Christian mysticism, ${ }^{19}$ Castaneda made the connection between

${ }_{11}$ The New Age discourse dominates the Czech alternative spiritual environment and contemporary shamanism imitates it. Therefore, there is a great deal of information about "energies", holistic approaches, etc. Cf. the term "New Age sensu lato" in Wouter J. HanegraAfF, New Age Religion and Western Culture: Esotericism in the Mirror of Secular Thought, New York: State University of New York 1998, p. 98-112.

12 Mircea Eliade, Shamanism: Archaic Techniques of Ecstasy, New York: Bollingen Foundation $1964,610 \mathrm{p}$.

${ }^{13}$ I have never heard my informants talking about Piers Vitebsky's or Thomas A. DuBois's monograph, although they have also been translated into Czech.

${ }^{14}$ The "sacred" in Eliade's point of view is the source of life, or a spring of meaningfulness. Cf. MIRCEA Eliade, The Sacred and the Profane, New York: Harcourt 1959, 256 p.

${ }^{15}$ Noel, The Soul of Shamanism ..., p. 30-34. Alternatively, Kocku von Stuckrad, The Scientification of Religion: A Historical Study of Discursive Change, 1800-2000, Boston and Berlin: De Gruyter 2015, $225 \mathrm{p}$.

${ }^{16}$ Boekhoven, Genealogies of Shamanism, p. 130.

17 Znamenski, The Beauty of the Primitive, p. 195.

${ }^{18}$ Castaneda's colleagues were, for instance, Peter Furst, Barbara Myerhoff, or Carlo Ginzburg.

${ }^{19}$ Znamenski, The Beauty of the Primitive, p. 174 
the "wise Indians" and Western seekers real: After all, if it was possible for him as a scholar, a non-native man of modern times to become a sorcerer's apprentice, right in the backyard of his home, why not for everyone else? ${ }^{20}$

Following the example of Castaneda's message, a whole new genre of shamanic literature with the same initiation structure has emerged: a white person who feels lost in their culture encounters an indigenous sage who shows them the foolishness of their haughtiness and reveals the truth about the world that the white person, after several failures, gradually understands. In the end, the sage explains that the apprentice is the 'chosen one' whose task it is to go back to their culture and spread the ancient wisdom in their homeland. In the Czech Republic, such stories are extremely popular, and authors such as Lynn Andrews, Taisha Abelar, Florinda Donner, Jeremy Narby, or Charles Hyemeyohsts Storm are widely translated. Even some contemporary shamans have adapted their life story to fit this frame.

Another key figure in forming a contemporary understanding of shamanism, Castaneda's peer and friend Michael Harner also hit the bulls' eye with his books. Besides, he shares with Castaneda a similar academic-shamanic career, which began with the study of hallucinogenic substances, ${ }^{21}$ followed by a shift from this fascination to the creation of a "sober" methodology, ${ }^{22}$ and quitting the academic career to become a spiritual leader. ${ }^{23}$

As one of the most influential authors and teachers for contemporary shamans, Michael Harner defended Castaneda continually. In response to Robert Bly's accusation that Castaneda "ransacks" Harner's ethnographic records of the Jivaro people, Harner protested: "Bly and de Mille are unaware that remarkable parallels exist in shamanic belief and practice thorough the primitive world." ${ }^{24}$ And he is indeed right - although only from the perspective of Eliade's generalizing methodology only.

He stands up for Castaneda even in his most famous book The Way of the Shaman (1980), ${ }^{25}$ which is both a book reflecting his anthropological knowledge and a practical guide on how to enter the shamanic world. Right at the beginning of this book, Harner made a statement: "The books of Carlos Castaneda, regardless of the questions that have been raised regarding their degree of fictionalization, have performed the valuable service of introducing many Westerners to the adventure and

${ }^{20}$ Note, that "the U.S. play the role of a bastion of rationality and intellectual safety, whereas Mexico is presented as a mysterious 'camposcape”. Zuzana Marie Kostićová, “From Academic Anthropology to Esoteric Religion: the Development of Carlos Castaneda's Writings”, under review in Aries: Journal for the Study of Western Esotericism. Cf. ZnAmenski, The Beauty of the Primitive, p. 206.

${ }^{21}$ In Harner's case, the anthropological research among the Jivaro people. Michael HaRner, The Jivaro: People of the Sacred Waterfalls, Berkeley: University of California Press 1972, 233 p.

${ }^{22}$ In Harner's case, the drumming, in Castaneda's case, the invention of Tensegrity.

${ }^{23}$ Michael Harner has founded in the 1987 Foundation for Shamanic Studies. Carlos Castaneda formed a small group of loyal adherents.

${ }^{24}$ Richard de Mille is the main debunker of Castaneda's fraud. Richard De Mille, The Don Juan Papers: Further Castaneda Controversies, Belmont, CA: Wadsworth 1990, p. 40.

${ }^{25}$ Michael Harner, The Way of the Shaman: A Guide to Power and Healing, San Francisco: Harper \& Row 1980, $171 \mathrm{p}$. 
excitement of shamanism and to some legitimate principles involved." ${ }^{26}$ In return, on the back cover of the same book, Castaneda sang Harner's praises: "Wonderful, fascinating ... Harner really knows what he's talking about." No wonder that the basic shamanic courses of Michael Harner's Foundation for shamanic studies (FSS) introduce these two as pioneer mediators of shamanic practice; a couple of men who "provide the privier view into shamanism". ${ }^{27}$

\section{Carlos Castaneda and his work}

Castaneda was undoubtedly a controversial man, and so all the shamans I have spoken to felt obliged to comment on Castaneda's personality and life story. They overwhelmingly described Castaneda as a cult leader, a sectarian, a great manipulator, or simply "a weirdo" and they mostly agreed that Castaneda made his stories up. This criticism notwithstanding, they credited Castaneda with discovering the previously less travelled road. As one shaman puts it: "Whatever Castaneda was, he has built a few bridges across the unknown field, a few slabs, which were not there before. So, thanks to him we can get there because we at least have something that is described, named and we can hold it. [...] We shall thank Castaneda for that." ${ }^{28}$

As for the literary style - some shamans found his books wordy or phantasmagorical (the descriptions of mescaline trips), although some of my respondents appreciated his "Carlitos" stylization in which a book character becomes deliberately more obtuse than any reader. According to contemporary shamans, this literary technique helped Castaneda to mediate Don Juan's knowledge to the broader audience since there is an agreement that Castaneda possessed some actual indigenous knowledge after all. Nevertheless, Castaneda "dragged out" the whole book series needlessly. So, consequentially, none of the shamans read Castaneda's decalogy thoroughly. In most cases, they gave up the reading by the third book (Journey to Ixtlan) $;{ }^{29}$ only one kept following Castaneda's teachings to the fifth book (Second Ring of Power). ${ }^{30}$

This fact corresponds to how Castaneda usually gets reflected mark in the shamanologic academic milieu - in connection to the image of shamanism, mainly his first three monographs are mentioned: The Teachings of Don Juan, ${ }^{31} \mathrm{~A}$ Separate Real$i t y,{ }^{32}$ and Journey to Ixtlan. This copies the literary style and message of Castaneda's books: from anthropological works on shamanism (or its imitation) to his mystical

${ }^{26}$ HARNER, The Way of the Shaman, p. xxi.

27 The course “The way of the Shaman”, held by FSS on April 22.-24., 2017.

${ }^{28}$ Interview with shaman J., May 23rd, 2018.

29 Carlos Castaneda, The Journey to Ixtlan: Further Conversations with Don Juan, New York: Simon \& Schuster 1972, 268 p.

${ }^{30}$ Carlos Castaneda, The Second Ring of Power, New York: Simon \& Schuster 1977, 316 p.

31 Carlos Castaneda, The Teachings of Don Juan; A Yaqui Way of Knowledge, Berkeley: University of California Press 1968, 196 p.

32 Carlos Castaneda, A Separate Reality: Further Conversations with Don Juan, New York: Simon \& Schuster 1971, 317 p. 
teachings. The shamanic criticism of his life and lack of interest for his later books mirror this development as well.

When considering the authenticity of Castaneda's work, opinions can be divided into two categories. The first point of view is that Castaneda made it all up. One legend - as my respondent told me - goes that he was an impostor, who plagiarized Barbara Myerhoff's diploma thesis, but his fraud was exposed at the university, so he changed his mind and published this text as a novel..$^{33}$ The soft version of Castaneda's hoax explanation is that he might have stolen the identity of a Mexican shaman, and corrupted his teaching in many points. However, the true "native" core remains, and therefore the books are worth paying attention to - albeit with a cautious and thorough analysis.

The second point of view is that Castaneda made it all up as well. Nonetheless, the results are different. These shamans do not care about the Native American copyright, because Castaneda's works might hold true in spite of it. To understand this position, note that there is a deep consensus in the current shamanic milieu, that Eliade's and Harner's upper and lower worlds are just "layers" of this reality. This reality is perceived as multidimensional. In conclusion, Castaneda's teachings are truths from another dimension of reality. A similar rank of explanations clarifies that Castaneda channelled his teachings, which is also a valid method for obtaining information in contemporary shamanism.

Since Castaneda's books possess many questions and doubts, one must be particularly vigilant while reading them, for many things "work", but at the same time, Castaneda allegedly got tangled up in the native teachings and made the information complicated, confusing, and misleading. Therefore, these books are not recommended for shamanic beginners, and I have been urged to read Castaneda's book carefully. The books retain many useful observations, but frequently contain Castaneda's fabrications and even projections and "personal demons".

A good example of such a misinterpretation according to one shaman is the awareness of water (cf. Separate reality). ${ }^{34}$ After a bad experience, Don Juan forbids Carlos to even come close to water, but as the shaman puts it: "One can start to fear moist hollows in the forest, because of evil spirits. But I think, in this case, it's just about Castaneda's fear; perhaps an intentionally written bogeyman ..."35

I assume that we could find one underlying cause for these ambivalent interpretations of Castaneda's legacy: Even though current shamans know about the pitfalls of Castaneda's work and are aware of his life story, his literary legacy is still too good to be rejected. The "fraudulent", "fictional" or "non-historical" character of Castaneda's work did not cause the rejection of his work, because, after all, it has no relevance to

${ }^{33}$ To correct the inconsistencies: The Teachings was indeed Castaneda's master's thesis. He was then awarded a Ph.D. for Journey to Ixtlan in 1973. Castaneda did not plagiarize; but nevertheless, he "borrowed" some motives from Myerhoff's Huichol informant.

34 "He stressed that I had to avoid water and keep it from touching the surface of my body for three or four months." CASTANEDA, A Separate Reality, p. 180; cf p. 214.

${ }^{35}$ Interview with shaman J., May 23rd, 2018. 
the shamans' needs. Religious (spiritual) life is influenced, co-created, and supported by storytelling, myths, novels, movies, art, and symbols that are touching and moving without necessarily being historically accurate. Provided that current shamanism is a religion or religious practice in the broad sense, Castaneda can be considered one of its influential sources. Considering this claim, let us have a closer look at Carlos Castaneda's literary and factual impact in the Czech shamanic environment.

\section{Carlos Castaneda's legacy in the current Czech shamanism}

Contemporary Czech shamans ${ }^{36}$ first encountered Carlos Castaneda's work very early after the fall of the Iron Curtain. In 1992, the first translation of the first book of Castaneda's decalogy was published; the famous The Teachings of Don Juan ${ }^{37}$ However, the significance of his books for the ethos of Czech shamanism is not as strong as in the USA. Instead, his thoughts and concepts only became better known through the work of Michael Harner and the works of Castaneda's followers, whether direct (Taisha Abelar or Florinda Donner ${ }^{38}$ or secondary ones, such as Victor Sanchez..$^{39}$ The list of Castaneda's apologists would not be complete without Miguel Angel Ruiz Macias's Four Agreements ${ }^{40}$ (and its sequels) ${ }^{41}$. This book also deserves mentioning, as it has been a spiritual bestseller in the Czech Republic since its first translation in $2001{ }^{42}$ Due to its great acclaim, the book was reprinted for the third time, and got an

${ }^{36}$ There is no historical evidence for shamanic tradition in the territory of the Czech Republic. However, the lack of historical continuity does not automatically allow us to call contemporary shamans "inauthentic". Cf. Susannah Crockford, "Shamanisms and the Authenticity of Religious Experience", in Pomegranate: The International Journal of Pagan studies 12 (2002): p. 139-158.

37 Unfortunately, this translation was more enthusiastic than professional. CARLOS CASTANEDA, Učení dona Juana, Praha: Reflex 1992, 187 p.

38 Taisha Abelar, The Sorcerers' Crossing: A Woman's Journey, New York: Viking Arkana 1992, 252 p.; Florinda Donner, Shabono: A Visit to a Remote and Magical World in the South American Rain Forest, New York: Delacorte Press 1982, 305 p.; Florinda Donner, The Witch's Dream: A Healer's Way of Knowledge, New York: Simon \& Schuster 1985, 287 p.; Florinda Donner, Being-in-Dreaming: An Initiation Into the Sorcerers' World, New York: HarperCollins, 1992, $320 \mathrm{p}$.

${ }^{39}$ Victor Sanchez, The Teachings of Don Carlos: Practical Applications of the Works of Carlos Castaneda, Rochester: Bear \& Company 1991, 229 p.

40 Don Miguel Ruiz, The Four Agreements: A Practical Guide to Personal Freedom, San Rafael: Amber-Allen Publishing 1997, 160 p.

${ }^{41}$ Don Miguel Ruiz, The Four Agreements Companion Book: Using The Four Agreements to Master the Dream of Your Life (A Toltec Wisdom Book), San Rafael: Amber-Allen Publishing 2000, 224 p.; Don Miguel Ruiz, The Voice of Knowledge: A Practical Guide To Inner Peace, San Rafael, Amber-Allen Publishing 2004, 234 p.; Don Miguel Ruiz and don Jose Ruiz, The Fifth Agreement: A Practical Guide to Self-Mastery (Toltec Wisdom), San Rafael: Amber-Allen Publishing 2009, 248 p.; Don Miguel Ruiz, The Three Questions, New York: HarperCollins 2018, 208 p.

${ }^{42}$ Don Miguel Ruiz, Čtyři dohody: Kniha moudrosti starých Toltéků: Praktický prưvodce osobní svobodou [The Four Agreements: A Practical Guide to Personal Freedom], Hodkovičky: Pragma 2001, 135 p. 
adaptation in the form of a one-man-show play by the popular actor and esotericist Jaroslav Dušek, which has been selling out for many years. ${ }^{43}$

Another influential figure is a Czech author who publishes his books under the pseudonym Gato. ${ }^{44}$ In his books Uniknout Orlovi (To Escape the Eagle ${ }^{45}$ and Učení Nagualu (The Teachings of Naguals), ${ }^{46}$ he summarizes Castaneda's teaching in a systematic and attractive way - albeit with some dose of romanticizing and highlighting the less-problematic passages of Castaneda's teachings and Gato's own comparison between Castaneda's teachings and Zen Buddhism.

Having a rough picture of the literary corpus Czech shamans regularly read, associate, and compare with Carlos Castaneda's work, let us move on to my shamanic respondents. All the respondents I have interviewed knew Carlos Castaneda and were familiar with his books, and many even read them. Despite this general familiarity, it should also be noted that out of the twelve respondents, only three felt the need to reflect on and evaluate Castaneda's work to a greater extent. Moreover, all three of them had had the same mentor in their shamanic beginnings, so the course of this interpretation has quite a clear motivation. For the other shamans I interviewed, Castaneda was not of a major importance in their spiritual journey. He was "merely" one of many, and this restriction will be relevant throughout the analysis.

To balance this disclaimer out, we shall also mention that all the three abovementioned shamans have been practicing shamanism for a long time and are well-known in the esoteric milieu. Moreover, during the years of their professional careers, they have managed to pass their worldview, observations, and convictions on to hundreds of course attendees, long-term students, future shamans, and clients they have treated. Their opinion is therefore not insignificant in the Czech shamanic community.

The same can be said for the importance of the above-mentioned authors, who wrote their books under Castaneda's literary influence (i.e. Sanchez, Abelar, Ruiz, Gato). Harner's FSS also held their seminars in the Czech Republic and Harner's vision of shamanism has significantly impacted the Czech audience, spreading the positive image of Castaneda presented by this organization.

Finally, the impact of the abovementioned "meta-tutor" is not negligible as well, since she was the main and first active shamanic influencer in the Czech Republic,

${ }^{43}$ Local newspapers reported that tickets for the performance were sold illegally for four times the usual price. FiLIP JaRošEvskÝ, "Jaroslav Dušek a Čtyři dohody jdou proti překupníkům lístkủ” [online], Metro.cz, 18. 1. 2018, [1. 9. 2019] available online at https://www.metro.cz/jaroslav -dusek-a-ctyri-dohody-jdou-proti-prekupnikum-listku-p51-/spolecnost.aspx?c=A180117 _175703_metro-spolecnost_jsk.

${ }_{44}$ The same person translated Harner's The Way of the Shaman into Czech. Michael Harner, Cesta śamana: jak probudit svưj vnitřni potenciál [The Way of the Shaman: A Guide to Power and Healing], Praha: DharmaGaia 2010, 204 p.

${ }^{45}$ Gato, Uniknout Orlovi: čarodějné učení dona Juana v devíti knihách Carlose Castanedy [To Escape the Eagle: Magical Teaching of don Juan in Nine Books of Carlos Castaneda], Brno: Ohnisko 1994, $53 \mathrm{p}$.

${ }^{46}$ Gato, Učení Nagualì: z knih Carlose Castanedy, Florindy Donnerové, Taishy Abelarové a vlastních zkušeností [The Teachings of Naguals: from Carlos Castaneda's, Florinda Donner's, and Taisha Abelar's Books and My Own Experiences], Praha: DharmaGaia 1999, 165 p. 
mainly in the 1990s. ${ }^{47}$ She brought up the whole first generation of current professional shamans, and countless people have passed through her courses over the twenty-five years of her practice.

Considering the impact of Castaneda's legacy, let us focus more precisely on the similarities and differences of Castaneda's perspective and the shamanic worldview, starting with the similarities and prevalent ethos, complemented with the renounced parts of Castaneda's work, and finishing with the famed teaching about "dreaming and stalking", and its current use in a shamanic context.

\section{Shared ethos and objectionable teachings}

\section{The living nature and shamans' allies}

Contemporary Czech shamanism is, amongst other things ${ }^{48}$ massively influenced by environmentalism (stressing the importance of the nature and environmental sustainability), current pagan traditions (stressing the ritual practice), and the discourse of the New Age milieu; all of which co-create the shamanic worldview. The esoteric cosmology teaching that an all-penetrating energy intertwines with everything is omnipresent in shamanism..$^{49}$ Moreover, contemporary shamans share the idea, that this world (with all its layers and energies pervading from the universe into the psyche) is alive and talks to us. We should therefore pay attention to the voices of the world. Shamans share this concept with Castaneda; especially the listening to the bird-guides, to whom Castaneda also tried to listen during his apprenticeship. ${ }^{50}$

As a result of this philosophy, many shamans offer "accompanied journeys". These pilgrimages consist of wandering across the land with clients. The shaman listens to the client and draws their attention to the "nods of nature" 51 - the wind blowing, significant places in the countryside, the birds singing, or the direction, the wind is coming from, etc.; much in the same way as Don Juan did with Carlos.

The nature, in the current shamanic point of view, is not only listening to our thoughts or feelings; it is also patient, helpful, and frank; it is the Mother Earth. Furthermore, there are no malevolent beings in this world, or their number is only marginal..$^{52}$ The same holds true for shamans' allies, i.e., power animals, shamans' helping spirits. They are friendly fellows, sincere mentors, and guides through the other worlds. All current shamans identify with Michael Harner's teaching that the

47 This "meta-tutor" is currently involved in establishing a small community of adherents. She does not give interviews and wants to stay out of the media (note the similarity to Carlos Castaneda).

${ }^{48}$ Concepts such as karma, aura, Stanislav Grof's holotropic breathwork, homeopathy, etc.

${ }^{49}$ Cf. Exnerová, Šamanismus v rozhovorech, p. 69-70 (chap. "Energie a práce s ní" [Energy and the work with it]).

${ }^{50}$ Castaneda, A Separate Reality, p. 160.

${ }^{51}$ Interview with shaman I., June 26th, 2018.

52 Those rare malignant beings are not evil in their nature - either they are beyond our moral concepts since they came from far away, or their behaviour is a result of their suffering - they cannot act differently, but there is a chance to help them. 
shaman's ally is always helpful and kind. At the initial seminars of the FSS, the power animal is the first thing the future shamans seeks. It usually comes to the course participant peacefully and they have a polite conversation. The atmosphere is similar to Castaneda's coyote experience. ${ }^{53}$ But Don Juan explained to Carlos that he met a luminous being, but certainly not an ally.

Gaining an ally is the sorcerer's final exam in Castaneda's world and it is not easy to pass. The ally will "tackle" ${ }^{54}$ the apprentice. They will "spin" and "trill", ${ }_{55}^{5}$ and finally the ally has to be "beaten down" ${ }^{66}$ This perception lies in sharp contrast with the world of current shamanism, in which obtaining an ally is one of the first achievements. However, this is not the first difference between Castaneda's cosmology and that of the current shamans. First and foremost, Castaneda teaches his readers that the world is a dangerous place where enemies are lurking around every corner, and the presence of death is incessant. This attitude is similar to the world of Siberian shamans. The fact that everything is alive stands for "We are surrounded by enemies". ${ }^{77}$ The beings that live in our world are of a predator-ish nature; there is no space for negotiation left. Therefore, Don Juan teaches Carlos how to protect himself and fight against these forces creeping around the Sonoran Desert. Even though the world is a hostile place to live, in his books Castaneda is sometimes moved by its breath-taking beauty. However, this is more an existentialist position conscious of the fragility and transience of every moment, rather than the ingenuous confidence of contemporary shamans.

\section{The shaman's image and purpose}

In the next step, Castaneda destroys the romanticizing image of the shaman as a non-selfish (beyond selfish) being, which cures, helps, and navigates clients, teaching them how to live a happy life, how to shed the burdens of past, or how to give their life a meaningful narrative. Castaneda's shaman is a lone warrior, unbound from the nets of relationship. That cannot pass unnoticed. As one shaman puts it: "This is one great weakness of Castaneda's; that he made the outer world evil. Until you have a sword, don't you dare go out; be a brawler from the very beginning. That implies a dispute from the beginning." ${ }^{8}$ Instead of this model, this shaman suggests an "adventurer archetype". This adventurer does not prevent an argument by a hook or a crook, because they are entering the unknown landscapes of their own consciousness and other realities. However, while doing so, they enter these realms with humility, friendliness, and responsibility for their actions.

\footnotetext{
53 Castaneda, Journey to Ixtlan, p. 250-252.

54 Castaneda, Journey to Ixtlan, p. 250-252.

55 CAstaneda, Journey to Ixtlan, p. 197.

56 Castaneda, Journey to Ixtlan, p. 197.

57 Ronald Hutton, Shamans: Siberian Spirituality and the Western Imagination, London: Hambledon Continuum 2007, p. 60-61.

${ }^{58}$ Interview with shaman J., May 23rd, 2018.
} 
The aim of the warrior's alienation is evident in Castaneda's opus: There is supposedly a force in this world, called the Eagle, which controls human fate and consumes the human consciousness in the moment of death. The shaman is directed to accumulate enough power to escape from Eagle and not lose consciousness, at any cost. The way of shaman is, therefore, demanding, dangerous, and self-centred.

Moreover, in Castaneda's perspective, this shaman-warrior is the chosen one. The sorcerer, the nagual, or the warrior is able to recognize another being of their kind by emanating an inner light. The future shamans do not choose their way willingly. On the contrary, the shamanic teacher has to seduce them, entice them. "I've told you already, only a crackpot would undertake the task of becoming a man of knowledge of his own accord. A sober-headed man has to be tricked into doing it." ${ }^{59}$ They compare the willing aspirants to "leaking gourds".

What a stark contrast to modern Czech shamanism. The ambiance is democratic and inclusive: everyone is welcome to join the courses and try the shamanic techniques and combine them with previously acquired knowledge. Shamanic seekers come to these courses on their own, willingly paying considerable amounts of money. In Castaneda's terms, contemporary shamanism would be full of gourds.

Today's shamans find Castaneda's approach quite harsh in many points and their criticism usually means contradicting his claims as in the following citation: "There was never a black Eagle, which would swallow people. It doesn't exist. It's just trumped up. [...] The principle of accumulation [of power] is not shamanic; the core of shamanism is cooperation.. ${ }^{\prime 0}$ Michael Harner was not enthused by Castaneda's concept of the crude nature of shamanism as well, since he focused predominantly on healing methods. Nevertheless, once again, he excused Castaneda's ideas. According to him, Castaneda was only describing the "warrior (or sorcerer) type of shamanism". ${ }^{6}$

\section{Shaman's responsibility and neutral Power}

To focus more on the ethos which unites these two quite distinctive worlds, let us take note of two elements: the absolute responsibility for one own's fate and the nature of the world. The first statement is represented by pervasive assertions that a man creates his own destiny. The participants of shamanic courses are encouraged to stress that they are exactly where they are meant to be in their lives; or where they have caused themselves to be. Taking full responsibility for one's state of affairs is also the first step to initiating the treatment.

Castaneda accentuates this facet as well, although in a blunter style. Don Juan keeps mocking Carlos for his weakness, lack of tenacity, and self-pity. He agrees with many contemporary shamans: "You are here, with me, because you want to be here. You should have assumed full responsibility by now, so the idea that you are at the mercy of the wind would be inadmissible." ${ }^{2}$

${ }^{99}$ Castaneda, A Separate Reality, p. 18.

${ }^{60}$ Interview with shaman I., June 26th, 2018.

${ }^{61}$ HARner, The Way of the Shaman, p. XXI.

${ }^{62}$ Castaneda, Journey to Ixtlan, p. 92. 
The final topic we will focus on is the nature of the world. The previously mentioned comparison of the nature of Castaneda's perspective and the shamanic worldview shows that they are rife with contradictions. While Castaneda's world is hostile, the shamanic world is affable; while Castaneda's way of the sorcerer is an elite, debilitating commitment, the way of the current shaman aims to be for anyone, comfortably-and-open-accessed. While Castaneda's archetype is the warrior, the shamanic ideal is a discoverer, an adventurer, and a healer; while gaining the ally is a brawl for Castaneda, current shamans see it as the earliest goal, etc.

Despite the impression that these worlds could not be more different, I presume that their nature is at least in some points similar. Let me justify this claim more accurately. The worlds of Castaneda and modern Czech shamans manifest contradictorily, although it could be seen as a mere by-product of a similar nature, which is neutral. The Eagle, hostile spirits, the malevolent intentions of other sorcerers are not personal in the strict sense in Castaneda's world. These malevolent beings are far from judging or punishing anybody. They do not desire to settle the bill.

The same is true for the contemporary shamanic worldview. Its cosmology might seem more positive, even naive with all the overwhelming love of Mother Nature and other cosmic beings, but the all-penetrating energy is neutral as well. Our cosmos is formed by a neutral, impersonal power, which can be charged by positive or negative deeds. That corresponds with the shamanic ability to change the reality and the "cosmic responsibility" for one's fate. Subsequently, the rules are set out in both cases, and both the modern shaman and Castaneda's sorcerer work by the book.

As one shaman summarize this: "I am interested in Toltecs because every religion or religious system has a being, which really cares about them, helps them, does matter. Whereas Toltecs are the first ones, I've encountered, who say: 'But he does not matter. It is a power by itself. It does not give a damn. Either you will play by following its rules, and you will protect yourself, or you won't and then tough luck for you."'63

\section{Conclusion}

Even though, Carlos Castaneda is accepted as an essential figure in shamanic print culture ${ }^{64}$ current Czech shamans are more impressed by his sorcerer's apprentice story, than his specific teachings or advice. They differ from him in many perspectives on central shamanic terms; in behaviour and the way they explore the shamanic world; and in the degree of participation on shamanic practices. Today's shamans have refused many cornerstones of Castaneda's teaching, and left many of them unnoticed (for instance, the tonal-nagual dichotomy ${ }^{65}$ or the art of stopping the

${ }^{63}$ Interview with shaman V., July 12th, 2018.

${ }^{64}$ ZNAMENSKI, The Beauty of the primitive, p. $200 \mathrm{ff}$.

65 The whole second part of Carlos Castaneda, Tales of Power, New York: Simon \& Schuster $1974,278 \mathrm{p}$. 
world $\left.{ }^{66}\right)$. Although the nature of the world is comparable in both cases and they share the concept that the individual is a creator of their own destiny, the mood and approach differ considerably.

A good, self-explanatory example of the real form of Carlos Castaneda's legacy is the case of dreaming and stalking, the cornerstones of Castaneda's shamanic universe. Castaneda describes dreaming as a technique of controlling attention, or more specifically as a technique of controlling dreams. Don Juan encourages Carlos to learn to concentrate on his hands while dreaming and then gradually widen that view until he can travel in dreams and master the overall situation of the dream. ${ }^{67}$ This technique aims to create a "double" who can "accomplish feats that would be unimaginable under ordinary terms". ${ }^{68}$

Stalking is another sorcerer's skill. A stalker traces the strength..$^{69}$ Stalking requires flawless observation of the world's order which leads to mastering every situation by seven rules. The stalker also masters a method of recapitulation, which is actually stalking oneself. By re-actualizing and realizing every single moment, the stalker can create a substitution for his consciousness: "since awareness is the Eagle's food, the Eagle can be satisfied with a perfect recapitulation in place of consciousness". ${ }^{70}$ That is how the stalker escapes the Eagle's talons.

To sum up, these two methods are obviously rooted in more complex teachings, linked, connected, and explicated for some purpose. Contemporary shamans, however, simplified, decontextualized, and twisted the dreaming and stalking method completely, while simultaneously referencing Castaneda's legacy and his alleged "indigenous" insight.

In a nutshell, in current shamanism dreaming means a conscious entry into a changed state of consciousness, mainly the trance, which is induced by meditation or drumming. Harner does not recommend sleeping, as it is not easy to flee from a dream. ${ }^{71}$ And stalking equals thinking. One of my respondents described stalking in the following way: "Shamanic dreaming is actually about going somewhere to find something out or to carry out something. Also, what is happening there is, in $99.9 \%$ of all cases, on a symbolic level. I get a piece of clear, accurate information, but it's not straightforward. To understand the message, I have to examine it. And that's stalking. In our culture, we would call it thinking about things. It means using our mind."72 Simply put, the current Czech shamanic environment sees dreaming as a mere visualization method and stalking as an analysis of this visualization.

This example stands as a final pars pro toto of Castaneda's legacy in contemporary Czech shamanism. Shamans have adopted many motifs, set phrases, and the main line

${ }^{66}$ Castaneda, Journey to Ixtlan, p. 111.

${ }^{67}$ Castaneda, Tales of Power, p. 11.

${ }^{68}$ Castaneda, Tales of Power, p. 45.

${ }^{69}$ Castaneda, The Second Ring of Power, p. 227-228.

${ }^{70}$ Carlos Castaneda, The Eagle's Gift, New York: Simon \& Schuster 1981, p. 234.

${ }^{71}$ HARnER, The Way of the Shaman, p. XX.

${ }^{72}$ Interview with shaman I., June 26th, 2018. 
of narration, but they are far from being literal or exact in the implementation. Their spirituality is made-to-measure, and Castaneda's existentialist struggle does not cause any great sentiments.

\section{REFERENCES}

PRIMARY SOURCES

Abelar, Taisha, The Sorcerers' Crossing: A Woman's Journey, New York: Viking Arkana $1992,252 \mathrm{p}$.

Castaneda, Carlos, A Separate Reality: Further Conversations with Don Juan, New York: Simon \& Schuster 1971, $317 \mathrm{p}$.

Castaneda, Carlos, Tales of Power, New York: Simon \& Schuster 1974, 278 p.

Castaneda, Carlos, The Eagle's Gift, New York: Simon \& Schuster 1981, 316 p.

CASTANEdA, CARlos, The Journey to Ixtlan: Further Conversations with Don Juan, New York: Simon \& Schuster 1972, 268 p.

Castaneda, Carlos, The Second Ring of Power, New York: Simon \& Schuster 1977, $316 \mathrm{p}$.

Castaneda, Carlos, The Teachings of Don Juan: A Yaqui Way of Knowledge, Berkeley: University of California Press 1968, 196 p.

Castaneda, Carlos, Učeni dona Juana [The Teachings of Don Juan: A Yaqui Way of Knowledge], Praha: Reflex 1992, 187 p.

Donner, Florinda, Being-in-Dreaming: An Initiation Into the Sorcerers' World, New York: HarperCollins 1992, 320 p.

Donner, Florinda, Shabono: A Visit to a Remote and Magical World in the South American Rain Forest, New York: Delacorte Press 1982, 305 p.

Donner, Florinda, The Witch's Dream: A Healer's Way of Knowledge, New York: Simon \& Schuster 1985, $287 \mathrm{p}$.

Eliade, Mircea, Shamanism: Archaic Techniques of Ecstasy, New York: Bollingen Foundation 1964, 610 p.

Eliade, Mircea, The Sacred and the Profane, New York: Harcourt 1959, 256 p.

Gato, Uniknout Orlovi: Čarodějné učení dona Juana v devíti knihách Carlose Castanedy [To Escape the Eagle: Magical Teaching of Don Juan in Nine Books of Carlos Castaneda], Brno: Ohnisko 1994, 53 p.

Gato, Učení Nagualü: Z knih Carlose Castanedy, Florindy Donnerové, Taishy Abelarové a vlastních zkušeností [The Teachings of Naguals: from Carlos Castaneda's, Florinda Donner's, and Taisha Abelar's Books and My Own Experiences], Praha: DharmaGaia $1999,165 \mathrm{p}$.

HARNer, Michael, Cesta šamana: Jak probudit svi̊j vnitřnípotenciál [The Way of the Shaman: A Guide to Power and Healing], Praha: DharmaGaia 2010, 204 p.

Harner, Michael, The Jivaro: People of the Sacred Waterfalls, Berkeley: University of California Press 1972, 233 p.

Harner, Michael, The Way of the Shaman: A Guide to Power and Healing, San Francisco: Harper \& Row 1980, 171 p.

JAROŠEVSKÝ, FiLIP, “Jaroslav Dušek a Čtyři dohody jdou proti překupníkům lístků” [Jaroslav Dušek and The Four Agreements Intervene against Scalpers][online], Metro.cz, 18. 1. 2018, accessed 1. 9. 2019, available online at https://www.metro.cz /jaroslav-dusek-a-ctyri-dohody-jdou-proti-prekupnikum-listku-p51-/spolecnost.aspx?c =A180117_175703_metro-spolecnost_jsk.

Ruiz, don Miguel, and don José Ruiz, The Fifth Agreement: A Practical Guide to SelfMastery (Toltec Wisdom), San Rafael: Amber-Allen Publishing 2009, 248 p. 
Ruiz, Don Miguel, Čtyři dohody: Kniha moudrosti starých Toltéků: Praktickýprůvodce osobni svobodou [The Four Agreements: A Practical Guide to Personal Freedom], Hodkovičky: Pragma 2001, 135 p.

Ruiz, don Miguel, The Four Agreements: A Practical Guide to Personal Freedom, San Rafael: Amber-Allen Publishing 1997, 160 p.

Ruiz, don Miguel, The Four Agreements Companion Book: Using The Four Agreements to Master the Dream of Your Life (A Toltec Wisdom Book), San Rafael: Amber-Allen Publishing 2000, $224 \mathrm{p}$.

Ruiz, don Miguel, The Three Questions, New York: HarperCollins 2018, 208 p.

Ruiz, don Miguel, The Voice of Knowledge: A Practical Guide To Inner Peace, San Rafael: Amber-Allen Publishing 2004, 234 p.

Sanchez, Victor, The Teachings of Don Carlos: Practical Applications of the Works of Carlos Castaneda, Rochester: Bear \& Company 1991, 229 p.

\section{SECONDARY SOURCES}

Boekhoven, Jeroen W., Genealogies of Shamanism: Struggles for Power, Charisma and Authority, Groningen: Barkhuis 2011, 383 p.

Crockford, Susannah, "Shamanisms and the Authenticity of Religious Experience", Pomegranate: The International Journal of Pagan studies 12 (2, 2010): p. 139-158.

De Mille, Richard, The Don Juan Papers: Further Castaneda Controversies, Belmont, CA: Wadsworth 1990, 529 p.

Exnerová, Helena, Český šamanismus v rozhovorech [Czech Shamanism in Dialogues], Praha: Dingir 2018, 228 p.

Hanegraaff, Wouter J., New Age Religion and Western Culture: Esotericism in the Mirror of Secular Thought, New York: State University of New York 1998, 580 p.

Hutton, Ronald, Shamans: Siberian Spirituality and the Western Imagination, London: Hambledon Continuum 2007, 220 p.

KeHoe, Alice Beck, Shamans and Religion: An Anthropological Exploration in Critical Thinking, Long Grove: Waveland Press 2000, 125 p.

Kostićová, Zuzana Marie, "From Academic Anthropology to Esoteric Religion: The Development of Carlos Castaneda's Writings", under review in Aries: Journal for the Study of Western Esotericism.

NeŠpor, ZdenĚK, and Olga Nešporová, "Religion: An Unsolved Problem for the Modern Czech Nation”, Czech Sociological Review 45 (6, 2009): p. 1215-1237.

Noel, Daniel C., The Soul of the Shamanism: Western Fantasies, Imaginal Realities, New York: Continuum 1997, 252 p.

Pharo, Lars Kirkhusmo, "A Methodology for a Deconstruction and Reconstruction of the Concepts 'Shaman' and 'Shamanism'”, Numen: International Review for the History of Religions 58 (1, 2011): p. 6-70.

Stuckrad, Kocku von, The Scientification of Religion: a Historical Study of Discursive Change, 1800-2000, Boston and Berlin: De Gruyter 2014, 225 p.

WAllis, Robert J., Shamans/Neo-shamans: Ecstasy, Alternative Archaeologies and Contemporary Pagans, London and New York: Routledge 2003, p. 306.

Znamenski, Andrei A., The Beauty of the Primitive: Shamanism and the Western Imagination, Oxford: Oxford University Press 2007, 434 p. 